\title{
AC 2007-398: HUMAN BEHAVIOR SKILLS IN ENGINEERING EDUCATION
}

Rose Mary Cordova-Wentling, University of Illinois-Urbana Champaign

Raymond Price, University of Illinois-Urbana Champaign 


\title{
Human Behavior Skills in Engineering Education
}

\begin{abstract}
This past decade has been characterized by a series of changes in engineering education, beginning with the recognition of the need to incorporate human behavior skills in engineering education. Now, it is important to understand the importance and benefits that human behavior skills can bring engineers as they apply their technical knowledge in today's ever-changing and multidisciplinary world. This paper will report and discuss what human behavior skills encompass, the importance of human behavior skills in engineering education, methods for teaching human behavior skills in engineering, and the future of human behavior skills in engineering.
\end{abstract}

\section{Introduction}

More than a decade ago, the American industry was satisfied with engineering graduates who were proficient on technical skills and attributes. However, the current dynamic world in which engineers operate require them not only to have an education in the technical disciplines of engineering, but furthermore, to have a balanced education in both technical and non-technical skills and attributes. "These days, engineering is typically practiced in teams with several engineers from different disciplines who work with contractors, business people, and sales and marketing personnel" (Hsu, 2004, p.54). Therefore, in order to get hired, and later on be able to have a successful long term career engineers need to be trained on human behavior skills so that they are able to talk, interact, and work with people from different backgrounds; be worldly; be leaders if the situation calls for it; be ethical; and know how to effectively conduct themselves at professional environments. This need for a more broad-based engineering education which incorporates human behavior skills as part of the engineering curriculum has been acknowledged within the last decade (ABET, 2004; Bjorklund \& Colbeck, 2001; Hsu, 2004; Nguyen, 1998).

In order to effectively talk about the incorporation of human behavior skills as part of university engineering curriculums, it is important to clarify what human behavior skills in engineering takes into account for the purpose of this paper. For the purpose of this paper, human behavior skills in engineering encompasses many of the skills that have been referred to as soft and/or non-technical skills in past literature. This paper focuses on the human aspects of these skills due to the fact that engineers are assumed to be technically competent, but the literature shows that they lack the people skills that are needed in order to have a successful long term career (ABET, 2004; Baren, \& Watson, 1991; Darling, \& Dannels, 2003; Manseur, 2003; Selinger, 2003).

\section{Human Behavior Skills for Engineers}

Over a decade ago, the U.S. engineering community (industry, academe, and government) collectively concluded that engineering students need to be trained on human behavior skills in order to succeed within the modern American industry, and that consequently, a change in engineering education needed to be made (Accreditation Board for Engineering and Technology, 2004). Since then, some actions have been taken to incorporate human behavior skills as part of 
the curriculum of university engineering programs. However, in spite of some increases in the last decade, human behavior skills in engineering continues to be limited.

Many authors in the literature have emphasized the human behavior skills engineers need in order to apply their technical expertise successfully. Selinger (2003) noted that non-technical skills, such as making decisions, setting priorities, working in teams, running meetings, and negotiating, that every engineer needs to be more effective in the workplace and happier in life. Orsted (2000) stressed the importance of human behavior skills, which govern behavior at meetings, towards colleagues, on the phone, and the way problems and conflict are approached are needed by engineers in the daily interaction with others. In addition, Hissey (2000) pointed out human behavior skills, such as teamwork, communication, leadership, and interpersonal skills that have a career enhancing value and may save engineers from downsizing. In addition, Nguyen (1998) pointed out human behavior skills and attributes such as communication, social, presentation, interpersonal, leadership, management, and team-working skills that engineers need to confront new challenges in the ever-changing and multidisciplinary field that constitutes engineering in today's global environment. Additionally, Manseur (2003) refers to the need of a "broad education that goes beyond traditional engineering topics and includes areas such as ethics, team work, oral communication, life-long learning, and an awareness of the impact of engineering on society to name just a few" (p.1). All the authors mentioned above brought attention to the human behavior related skills that engineers need in order to successfully apply their technical knowledge in today's ever-changing and multidisciplinary world.

In 1994, industry, academe, and government collectively concluded and stated that engineering students need to receive human behavior skills in order to be successful professionals within the modern American industry (ABET, 2004). Since then, several studies have also expressed this need by stating that human behavior skills are of particular relevance in the formation and success of the modern engineer (Bjorklund \& Colbeck, 2001; Eck, 2000; Hecker, 1997; Hsu, Nguyen, 1998; Porbahaie, 1994; Watson, 2000).

The need for human behavior skills in engineering was first recognized by industry and educational leaders. On one hand, industry leaders voiced concerns to the community that engineering graduates were not properly prepared to function within the American industry due to the fact that they lacked the ability to team effectively, and "had little grasp of concepts such as customer service, environmental sensitivity, social responsibility, and continuous quality improvement" (ABET, 2004, p. 2). On the other hand, forward-thinking educational leaders voiced concerns regarding the need to modify the engineering curriculum in order to better prepare engineering graduates to face the new challenges that the current engineering environment presented. In 1994, "industry and academe realized that their concerns were the same, [therefore] they began to mobilize through ABET, the organization responsible for setting the standards of engineering education" (ABET, 2004, p. 1). As a result, the Accreditation Board for Engineering and Technology (ABET) acknowledged this call from industry and educational leaders, and started working towards changing the standards of engineering education in order to guarantee that engineering students not only have an education in the technical disciplines of engineering but also in human behavior skills. Consequently, ABET instituted the Accreditation Process Review Committee which was formed by people representing all facets of the engineering community and was responsible of making 
recommendations to change the standards of engineering education. The final recommendations of this committee were "captured in the Vision for Change, published by ABET in 1995 and circulated to the engineering community the same year" (ABET, 2004, p. 1). By October 1995, the committee recommendations were already being instituted and new accreditation criteria, Engineering Criteria 2000, was developed. Since then, ABET has actively engaged in the change process to include human behavior skills in engineering (ABET, 2004; Lang, Cruse, McVey, McMasters, 1999).

This past decade has been characterized by a series of changes in engineering education, beginning with the recognition of the need to incorporate human behavior skills in engineering. Now, it is important to understand the importance that human behavior skills can bring engineering students in order to work towards providing students with opportunities to develop these skills.

\section{The Importance of Human Behavior Skills for Engineers}

Due to the fact that these days engineering is typically practiced in teams with people from different disciplines, educational, and cultural backgrounds, it is crucial for engineers to receive human behavior skills as part of their training. This section offers a review of the importance and benefits engineers can obtain by receiving opportunities to develop communication, teamworking, interpersonal, leadership, management, ethical, life-long learning, emotional intelligence, and creativity skills.

\section{Communication Skills in Engineering}

"Effective communication occurs when each party conveys ideas that are accurately understood" (Kaye, 1998, p.44). Possessing good oral and written communication skills is very important; in fact, it is the key of success at work, play, and at home (Kaye, 1998). As Baren and Watson (1991) noted, communication is an essential component of most engineers' jobs since practicing engineers spend 50 to $75 \%$ of their time on some form of written or oral communication.

Therein, lays the importance of providing engineering students with opportunities to develop good communication skills, which are as important as their technical training in their success as professional engineers.

"Most individuals graduating from a university feel relatively confident in their communication skills. While it is true that some have perfected these skills to a point where they are accomplished communicators, those really proficient individuals are still in the minority" (Hissey, 2000, p.1368). Today's fast paced, global, and competitive workplace requires engineers to convey technical information effectively, clearly, and quickly to audiences from diverse cultural and professional backgrounds (Darling, \& Dannels, 2003; Sageev, \& Romanowski, 2001). As several researchers have noted, communication skills such as translation, clarity, negotiation, and listening are vital to practicing engineers in order to be able to communicate problem definitions, solutions, and results; encourage implementation of solutions; reinforce positive responses; lead and/or effectively participate in training sessions, group meetings, and seminars; negotiate; clarify needs; create need awareness; handle 
objections; and translate technical information into a form that is simple and clear to understand, yet numerically rich (Dannels, 2002; Darling, \& Dannels, 2003; Eck, 1990; Rosenbaum, 1986).

The importance of communication skills in the workplace translates in the fact that one of the major requirements of today's recruiters is that new hires have excellent communication skills (Baren, \& Watson, 1991; Pet-Armacost, \& Armacost, 2003). Furthermore, "engineers who communicate well, therefore, stand out from others in their field and generally have more success in engineering pursuits, while those who communicate poorly often find themselves unable to advance, no matter what their technical expertise" (Robar, 1998, p.26).

In response to the importance and need of communication skills in engineering, several researchers and the Accreditation Board for Engineering and Technology (ABET) have stated the need to train engineering students in both oral and written communication skills (Baren, \& Watson, 1991; Darling, \& Dannels, 2003; Kitto, \& Sylvester, 2002; Passino, 1998; PetArmacost, \& Armacost, 2003; Porbahaie, 1994). Currently, most engineering curricula provide limited or no opportunities for students to develop communication skills (Baren, \& Watson, 1991; Darling, \& Dannels, 2003). "In many cases, Freshman Composition and a Technical Writing course are all that are required over the four year curriculum" (Baren, \& Watson, 1991, p.419). In addition, within engineering courses, communication skills are not taught explicitly; however, students are expected and held accountable for being able to speak and write well. Consequently, there is a need to change university engineering programs in order to provide opportunities for students to develop communication skills (Pet-Armacost, \& Armacost, 2003). The importance and need for oral and written communication skills in engineering has been clearly recognized. Engineering students who have good communication skills are more likely to succeed and advance in the professional world than those who don't.

\section{Team-Working Skills in Engineering}

In today's work environment, project tasks generally involve the establishment of teams formed by people from different functional departments of the company. In addition, many U.S. corporations work towards hiring the best and brightest people regardless of race, color, sex, religion, national origin, age, sexual orientation, or disability. Consequently, engineers should be prepared to work in team projects that are diverse and multifunctional in order to succeed in the professional environment (Chen, \& Lin, 2004; DiTomaso, \& Farris, 1992; Lovgren, \& Racer, 2000; Seat, \& Lord, 1999; Thamhain, 1992b).

Companies look for engineering graduates who are not only technically proficient, but who also have good team-working skills that allow them to "communicate and interact with other people in adaptive and contributing styles" (Seat, \& Lord, 1999, p. 385). Furthermore, in order to perform effectively within a company and get promoted, engineers need to be able to work successfully in teams and be team leaders should the situation call for it. Taking this into consideration, several researchers have stated the need for engineers to possess good teamworking skills (Braham, 1992; Chan, Ho, \& Tam, 2001; Dahir, 1993; Hawkins, \& Barclay, 1990; Simmons, 1999; Thamhain, 1992a; Yost, \& Mohankrishnan, 1998). In addition, the National Science Foundation (NSF) and the Accreditation Board for Engineering and Technology 
(ABET) have stressed the importance of preparing engineers to effectively work in team oriented environments (Lovgren, 2000).

Currently, many university engineering programs promote team-work by having students complete group projects. However, few teach students the necessary skills to perform effectively in a group environment before assigning team-work. Consequently, students may gain experience working in teams, but they may not gain effective team-working skills, which in turn may cause the team not to work successfully and/or to develop negative views about the value of team work (Chen, \& Lin, 2004; Lingard, \& Berry, 2002; Seat, \& Lord, 1999). "In order for students to benefit from these team projects, efforts must be made to ensure that the teams are well formed and given the knowledge and tools necessary to operate effectively" (Lingard, \& Berry, 2002, p. 1). Researchers have stated that a team operates effectively when team members agree on team goals, problems, and solutions; communicate effectively; hold themselves mutually accountable; trust each other; train and coach each other; listen and respect each other; have pride and enjoyment in group activity; have strong performance norms and resultorientation; and commit to team objectives (Chan et al., 2001; Lovgren, \& Racer, 2000; Ramirez, Velez-Arocho, Zayas-Castro, \& Torres, 1998; Thamhain, 1992b).

Possessing good team-working skills not only helps engineering students obtain jobs and advance in their careers, but it also makes their work life easier in the sense that by effectively working in diverse and multifunctional groups engineers can benefit from the creativity, ingenuity, and assistance of their co-workers. Having good team-working skills is essential for engineering students.

\section{Interpersonal Skills in Engineering}

Interpersonal skills "include the ability to read and manage the emotions, motivations, and behaviors of oneself and others during social interactions or in a social-interactive context" (North Central Regional Educational Laboratory). Today's work environment, in which engineers work on cross-functional teams formed by culturally diverse members who may not share common norms, values, or vocabularies but who do offer unique expertise, insights, and perspectives, has placed increased importance on an engineer's interpersonal skills (NCREL; Simmons, 1999).

Several researchers have stated that having good interpersonal skills allows engineers to build consensus, effectively manage conflict, be able to work with others and get a common understanding with them, effectively manage groups, enhance the strengths and abilities of others, use effective communication and persuasive strategies, listen well, understand and positively manage the emotions of others, and effectively manage their own behavior during social interactions (Dreyfus, 1991; Eck, 1990; NCREL; Simmons, 1999; Thomas, 1999).

Consequently, engineers who have good interpersonal skills are able to obtain jobs and advance in their careers easier and faster than engineers who just have a technical background. "Interpersonal skills play an important role throughout a career from engineer, to engineering manager, to organizational manager, and to executive" (Simmons, 1999, p.25). On the other hand, a weak understanding and inability to apply interpersonal skills can seriously limit an engineer's career (Simmons, 1999; Tao, 1993). 
For the most part, engineers currently learn and develop interpersonal skills by trial and error, humanity classes, and extracurricular activities. However, through these sources, engineers practice their interpersonal skills through peer setting rather than supervisor/subordinate management situations which are common in engineering practice (Simmons, 1999; Tao, 1993). By developing good interpersonal skills engineers can have a wide variety of benefits that will help them in their professional and personal lives.

\section{Leadership Skills in Engineering}

Leadership can be described as the ability to influence other people to follow through and accomplish meaningful results. Leadership also includes the ability to make decisions and assist peers and subordinates in maximizing the use of resources to reach a common goal. One can say that leadership is about coaching; developing others; mentoring; and sharing experiences, knowledge and insight (Crawford, 1998; DeLisle, 2000; Illinois Leadership; Petcher, 1997). As Crawford (1998) states:

We are now recognizing that leadership can and does occur at all levels of organizations and in all kinds of settings. Leadership is increasingly being recognized as an interactive process that takes place between members of an organization. It is not simply a skill employed by a person in a position of power within an organization. (p. 2)

Therefore, it is important that engineering students are presented with opportunities to develop leadership skills that will allow them to successfully work collaboratively with other people to change organizations, lead and/or participate in multidisciplinary engineering activities, build teams, motivate people, create organizational structures conducive to innovative and effective work, plan and facilitate meetings, solve problems, among others (Askew, \& Price, 2003; Thamhain, 1992b; 2004a).

"Increasingly, those who hire engineering graduates look for employees who are not only technically proficient, but who also have demonstrated leadership and initiative in team settings" (Yost, 1998, p.1). In addition, as Farr (1996) stated organizational influences such as global and increased competition are forcing junior engineers into more managerial and leadership roles. Therefore, in order to get hired and later on get promoted, today's engineers need to have good leadership skills. Consequently, as several researchers have stated, university engineering programs should provide students with opportunities to develop these skills (Ashley, 1993; Askew, \& Price, 2003; Brungardt, 1996; Farr, 1996).

\section{Management Skills in Engineering}

Engineering and management have been perceived as separate functions for a long time. But because the world is changing and organizations are downsizing, de-layering, restructuring and re-engineering engineer needs to stand out from others and management skills are one aspect which provide them the competitive edge over others. The need for management skills does not rise suddenly as an engineer is transformed from engineer to manager, but are developed as his/her career progresses. The probability and ease of the success are seen to be greatly 
enhanced if the engineer has mastered good management skills with sufficient technical knowledge of his/her discipline. (Redfem, 1997).

Lannes (2001) described the importance of the very concept of management skills and their importance to engineers. He stated there has been an increasing trend to give engineers management assignments earlier and earlier in their careers. ABET (2000) criteria confirms the importance of management skills from the initial career formation stage of the engineer during their undergraduate program. It is necessary for engineers to be well versed in management skills because they spend most of their working lives managing people more than technical problem solving. Most engineers work on teams and often it is necessary for them to take on the leadership role of the team, which may lead them to take up management of the team's projects (Richardson, 1996).

Thamhain (1993) indicated that the needs of the engineers should be addressed by including management skills in engineering education. He stressed the fact that most of the professional engineers who have had several years of experience believe that management skills are required and are essential to success in engineering. According to Visser (2005), management skills are important for engineers to improve their job performance, job satisfaction and promotion prospects. Management skills also provide engineers with the ability to provide clear direction and guidance to others, integrate multidisciplinary efforts, plan and obtain commitments, communicate effectively, provide problem-solving assistance, collect and filter relevant data valid for decision-making, and integrate individual demands, which benefits the overall engineering task (Visser, 2005)

Johnston (1987) reported that the majority of engineers are required to assume a degree of management responsibility as they approach mid-career, and for some, the opportunity may come even earlier. Management skills are also important since engineers are more likely to become entrepreneurs these days and the opportunity to start and grow their own successful companies requires them to learn effective management skills. Also engineers who start businesses are potential leaders and they must be able to find way to satisfy customers and produce successful profitable products (Gross, 2000).

\section{Ethical Skills in Engineering}

"A concern for ethical behavior has been a part of technological activity since the dawn of history" (Stephan, 2002, p.8). As early as 1940, the Accreditation Board for Engineering and Technology (ABET, then known as the Engineers' Council for Professional Development) showed interest in the introduction of ethical education in engineering programs by forming a committee on Principles of Engineering Ethics and conducting a survey on the teaching of engineering ethics. However, before 1975, no one spent much effort considering engineering ethics as a discipline in its own, in fact, the doing of engineering ethically remained simply something that most of the time people did because they did not want penalties against them, but not because it was the right thing to do. Engineering ethics started being considered a discipline in its own when the post-Watergate era, the Vietnam War, and the environmental movement contributed to the force of cultural factors which encouraged academics to look for practical problems (such as engineering ethics) to address. Consequently, the National Science 
Foundation and the National Endowment for the Humanities encouraged studies on engineering ethics, which caused the field to become an established and recognized discipline. The subject of engineering ethics is now a full-time study by numerous researchers (Davis, 1999; Herkert, 2000; McGinn, 2003; Steneck, 1999; Stephan, 2002).

"The last quarter of the $20^{\text {th }}$ century witnessed many notable changes in engineering education in the USA, including growing recognition of the importance of ethics and social responsibility" (Herkert, 2000, p.303). This acknowledgement of the importance of ethics in engineering has been spurred on by academic institutions, engineering employers, researchers, and ABET's Engineering Criteria 2000, which requires that engineering programs demonstrate that their graduates have an understanding of professional and ethical responsibility (Bekir, Cable, Hashimoto, \& Katz, 2001; Herkert, 2000; Hissey, 2000; Passino, 1998; Stephan, 2002; Stern, \& Pimmel, 2002). The importance of incorporating ethical education in engineering programs lies on the need of properly preparing engineering graduates for their careers. As Stern and Pimmel (2002) stated,

An engineer's work can have significant impact on society; therefore the practice of engineering carries certain obligations and responsibilities. Engineers need to assess both positive and negative impacts of particular engineering solutions, to inform society of these impacts, and to gain informed consent before a particular solution is implemented. Engineers need to act ethically, to recognize and resolve potential conflicts of responsibilities to society, to employers, to fellow workers, and to self. (p.13)

In addition, Stephan (2002) states the importance of providing engineering students with opportunities to develop ethical skills by saying that, "in the engineering world of the future, a sound understanding of the theoretical and practical sides of engineering ethics will be as necessary to the proper education of engineers as a knowledge of differential equations is today, if not more so" (p.7). Stephan (2002) supports this statement by saying that engineering ethics is now an established discipline that deals with practical problems; engineering work is now more complex than ever, and its ethical effects can no longer be dealt with simple intuition; and that engineering students need classroom practice to understand and deal with the complex and subtle issues of professional responsibility in engineering before they encounter ethical issues in the real world.

Ethical skills in engineering graduates are required by the members of the global workforce of the $21^{\text {st }}$ century (Hissey, 2000; Passino, 1998). In order to succeed in the professional world engineers need to have good ethical skills that allow them to have self-confidence in identifying and reasoning about moral problems, evaluate actions according to moral criteria, act morally, distinguish between ethical and unethical situations, and understand the consequences of their actions and their responsibility to society (Loui, 2004). Therefore, it is important that university engineering programs provide students with opportunities to apply their ethical principles to situations and problems that are peculiar to engineering (Loui, 2005; Stephan, 2002).

Currently, engineering programs across the United States are experimenting with ways to integrate engineering ethics to their curriculums. Nevertheless, Stephan (2002) determined that nearly $70 \%$ of university engineering programs do not require their students to take ethics-related 
courses. In addition, researchers have pointed out that few faculty members are familiar or comfortable teaching engineering ethics courses (Herkert, 2000; Honour, 1996). As noted, many challenges remain in order to fully incorporate engineering ethics as part of engineering curriculums.

\section{Life-Long Learning Skills in Engineering}

Over a decade ago, a group of experts estimated the half-life of an engineer's technical skills. Essentially they estimated how long it would take for half of everything an engineer knew about his [or her] field to become obsolete. For mechanical engineers, it was 7.5 years. For electrical engineers, it was 5, and for software engineers, it was a mere 2.5 years, less time than it takes to get an undergraduate degree. Today, those numbers are surely even smaller. (Smerdon, 1997, p.21)

The engineering profession is subject to continuous innovation; in order to maintain competitive advantage engineers must have a rapid response to the pressures of the global market by always being one step ahead in their incorporation of new knowledge into their products (Fink, 2001; Midwinter, 1999; Whittaker, 1989). Consequently, to remain professionally effective, and hence be able to maintain their jobs and advance in their careers, engineers must update their knowledge continuously throughout their professional endeavors (Fink, 2001; Midwinter, 1999; Smerdon, 1997).

Additionally, the importance and need of life-long learning skills in engineering lays on the fact that "as technological change accelerates and product lines rise and fall in ever-diminishing life cycles, engineers find themselves switching jobs more often" (Smerdon, 1997, p.21).

Furthermore, global competition has caused job security to be "a fond memory of yesterday's workplace" (Baldwin, 1996, p. 10). Therefore, engineers must have life-long learning skills in order to succeed in today's marketplace.

As Midwinter (1999) and Atkinson (1989) stated, having life-long learning skills allows engineers to stay highly marketable and compete more effectively in today's professional world. Therefore, as several researchers have stated, engineers must not think that their education in technical and human behavior skills ends after college, but they must see it as a lifetime project (Baldwin, 1996; Fink, 2001; Hecker, 1997; Midwinter, 1999; Smerdon, 1997). "Ultimately it is up to the individual to pursue lifelong learning of these skills, and it is the role of employers and educators to instill in a student the need and desire to hone these skills for the rest of their professional career" (Hecker, 1997, p.62).

\section{Emotional Intelligence in Engineering}

According to Goleman (1998), emotional intelligence "refers to the capacity for recognizing our own feelings and those of others, for motivating ourselves, and for managing emotions well in ourselves and in our relationships" (p.317). Various surveys and past research have identified that the engineering graduate requires many skills and a great deal of knowledge when entering the workforce. Essential for this are elements such as interpersonal skills, teamwork, communication, as well as a strong sense of motivation (Cookie \& Miggs, 2005; Burns \& 
Chisholm, 2002; Pearce, 1998; Reimer, 2003, Thomas, 1999). Such skills are particularly relevant in this era of globalization, which is taking place at an ever-increasing speed and provides an environment in which the modern engineer must interact. Engineering education programs need to be able to prepare graduates, not just with engineering fundamentals, but also for success and actual on-the-job skills. Essential for the skills set for an engineer includes capabilities in emotional intelligence (Goleman, 1999). Goleman identified five domains of emotional intelligence, namely: self-awareness; self-regulation; motivation; empathy; and social skills. These areas need to be incorporated into engineering students' educational programs in order to prepare them for their professional working life.

According to Kelley (1999), IQ gets you hired, but emotional intelligence (EI) gets you promoted. For example, managers at AT\&T Bell Labs were asked to rank their top performing engineers. High IQ was not the deciding factor, but instead how the person performed regarding answering e-mails, how good they were at collaborating and networking with colleagues, and their popularity/relationship with others were identified. A study conducted by the Center for Creative Leadership (1994) found that $75 \%$ of careers are derailed for reasons related to emotional competencies, including inability to handle interpersonal problems; unsatisfactory team leadership during times of difficulty or conflict; or inability to adapt to change or elicit trust.

A study conducted by Sunindijo and Hadikisumo (2005) focused on investigating the benefits of EI in project management in terms of leadership style, conflict resolution style and client satisfaction. Their study concluded the following in terms of growing sense of self awareness and its importance in overall development of emotional intelligence: (1) People with good selfawareness tend to delegate works to others and to motivate and bring out the best efforts in them. (2) People with good self-management have a proactive attitude and take an anticipatory action to avoid problems and also take advantage from available opportunities. (3) People with social awareness care and hear what other people are really saying. Caring and hearing indicates that the person is open and empathetic toward others.

Emotional intelligence furnishes a person with compassion, empathy, adaptability and selfcontrol. If persons strengthen their EI, then they also are more able to strike a healthy balance between personal needs and the needs of others (Segal, 1997). Emotional intelligence skills can be applied across different work environments. EI skills improve teamworking skills, especially with regard to communication between team members. Furthermore, the context of the receiver of the communication, whether it be written, non-verbal or oral, is taken into account through empathy and self-awareness. This is important whether the context be cultural, educational, professional, social or otherwise (Riemer, 2001).

Riemer (2003) noted that emotional intelligence offers various components that can improve communication skills of engineers. Furthermore, Reimer (2003) states that a lack of sufficient communication skills serves only to undermine the image of the engineer, but this can be tackled by engaging features of emotional intelligence in the education of engineers. Riemer emphasized that communication could be inhibited depending on the self-actualization of the communicator as it ties with EI elements of self-awareness and self-regulation. EI plays an important role in strengthening the communication skills of an engineer, which are considered as 
one of the primary attributes an employer requires from a new engineering graduate (Palmer \& Slavin, 2003).

Emotional intelligence is a prime factor in the success of the individual. Goleman (1998) asserted that emotional intelligence abilities were about four times more important than IQ in determining professional success and prestige, even for those with a scientific background. Furthermore, the engineer's stereotypical negative image of the socially inept genius can inhibit student recruitment and retention (Yurtseven, 2001). This may be countered through graduates employing EI skills in the workplace, thereby generating an improved image for engineers through interaction. However, these skills need to be taught to engineering students in their educational programs.

\section{Creativity in Engineering}

Sternberg (1999) defines creativity as the ability to produce work that is novel (i.e., original, unexpected), high in quality, and appropriate (i.e., useful, meets task constraints). Engineering is the creative application of scientific principles (Standler, 1998). Engineering requires innovation, creativity and flair focused in a design process. Design is at the heart of engineering and it's where professional engineers demonstrate their creativity and innovation (Felder, 1997). Given that the complexity surrounding every engineering project mounting as natural resources dwindle, the world population increases, and the global infrastructure and economy grow ever more intertwined, the creativity and innovation necessary to address the big issues facing civilization will only continue increase in importance (Stouffer, Russell, \& Oliva, 2004). Most engineering projects demand creative or innovative approaches in the design or equipment, systems, and facilities (Standler, 1998). While creativity is an essential component in engineering design, focused interviews with leading creative engineers has found that engineering schools do not adequately prepare students for creative endeavors or for the realities of modern industry (Richards 1998).

Engineers are not commonly perceived as creative professionals. A recent Harris Poll sponsored by the American Association of Engineering Societies and IEEE-USA found that "only 2 percent of the public associate the word 'invents' with engineering; and only 3 percent associate the word 'creative' with engineering (Bellinger 1998; Wulf 1998). Engineering as a profession has not been intentional about educating students to become creative in their application of their technical and professional skills. In other words, the value of creativity is not explicitly communicated to engineering students as a priority of their education (Stouffer, Russell, \& Oliva, 2004). Yet even in the most technical of positions, engineers must find novel and unique ways to approach and solve design challenges, whether this means placing piping in unique formations or finding a way to stabilize soil in a nontraditional manner.

Many engineering projects require significant communication, leadership, systems thinking, and creative problem solving. For example, designing today's big and complex highways and keeping them operational necessitated innovative and creative management techniques and construction methods, including the use of global positioning technology, laser measuring tools, and the use of slurry walls, ground freezing, and chemical stabilization of soil (Angelo 2001). According to Heller (2001), if engineers are to solve the critical issues surrounding the 
infrastructure, economic development, and the natural environment, then new and innovative solutions will be demanded to meet the needs of our greatly changed world. Infrastructure system life cycles need to be rethought and reengineered to serve their original purposes under new conditions, such as globalization, deregulation, telecommunications intensity, and increased customer requirements (Heller 2001).

Employers in many corporations consider creativity an important attribute when hiring new engineers. According to Munroe (1995), 70\% of the cost of a product is determined by its design, so that creative design can lead to substantial cost savings in corporations. As a result, creativity training for employees is becoming widespread (Clapham, 1997; Thackray, 1995). According to the 1995 US Industry Report, corporations are now budgeting billions of US Dollars for creativity training programs, and demand for training is said to be outstripping the supply of trainers (Hequet, 1995).

At the level of the individual engineer, considerations of the global marketplace and the creative skills regarded as essential for a successful career in engineering (Dekker, 1995) have also raised the issue of fostering creativity in engineering education (Steiner, 1998). A survey of engineering employers in the United Stated (Todd, Magleby, \& Sorensen, 1993), however, suggests that this training is not taking place, or is ineffective if it is. According to employers in the survey, three-quarters of new graduates are "unsuitable" for employment because of "skill deficiencies" in creativity, problem-solving, and independent and critical thinking.

Creativity can be a powerful tool to enhance technical efforts to solve engineering problems of all kinds. As one professor has stated: "As educators, we are responsible for stimulating creative thinking among our students .... Our ultimate goal is to require original creative work as part of every engineering course" (Richards 1998, p. 55). Snyder (1967), found that students at an American university who preferred trying new solutions dropped out of engineering courses three times more frequently than those who preferred conventional solutions. Taking a creative look at engineering education does not mean ignoring or choosing to disregard the normal project parameters or technical constraints that must be imparted to the next generation of professionals. Instead, using creativity can mean generating excitement in students as they approach engineering problems in original ways that have a tremendous impact on society (Raskin 2003).

\section{Methods for Incorporating Human Behavior Skills in Engineering Education}

There have been various methods that have been incorporated to enhance the human behavior skills of students in engineering programs. Some of the initiatives are describe below for each of the human behavior skills.

\section{Communication skills}

Engineering students need to improve their communication skills in order to meet job demands (Beer, 2002). The communication of information is an essential element of successful engineering practice, and the ability to communicate and use information effectively is critical to professional success and advancement of engineers. Feedback from industry rates 
communications and information use skills high in terms of their importance to engineering practice. Feedback from professional engineers and from engineers' supervisors concerning engineering competencies ranks communications and information use skills-the ability to write effectively, to make oral presentations, and to search out and acquire information-high in terms of importance to engineering practice. (Chisman, 1987).

At a number of universities, communication skills are taught in isolated classes, separate from the rest of the engineering curriculum. Other schools have chosen a "writing across the discipline" approach, to partner with a writing center, or to use a writing consultant (Walker, 2000). An example of a communication skills development program is the Writetalk

Communication System (WCS), which was developed by the engineering departments at Temple University, in conjunction with an outside consultant. The WCS was developed to address some of the most important communication skills required for a successful engineering career. The purpose of the WCS is to increase both student and faculty awareness of the importance of communication and to improve students' skills in reading, listening, written, and verbal communication. The WCS accomplishes this while students are involved in existing engineering academic programs (Baren \& Watson, 1991). Another example is the Department of Industrial Engineering and Management Systems at the University of Central Florida, which offer an introductory engineering course that covers professional development communication skills (e.g., oral, presentation, written, active listening). The introductory course is designed to expose students to the various engineering technical skills that they will need to develop during their entire program of study and to teach them some of the professional skills they will need to succeed in the workplace (Pet-Armacost \& Armacost, 2003).

\section{Team-working skills}

Some initiatives have been created to ensure that engineering students develop good teamworking skills that "allow them to communicate and interact with other people in adaptive and contributing styles" (Seat, \& Lord, 1999, p. 385). For example, Yost and Mohankrishnan (1998) implemented a formal cooperative learning component in engineering courses. Cooperative learning, which Yost and Mohankrishnan define as the instructional use of small groups so that students work and study together to maximize their own and each others' learning, has been documented in numerous studies to have a positive effect on the development of team-working, communication, and leadership skills in engineering students (Cavalier, Klein, \& Cavalier, 1995; Hilborn, 1994; McDonald, 1995; Smith, 1995; Yost, \& Mohankrishnan, 1998). According to Yost and Mohankrishnan (1998), in order to help students effectively develop team-working skills and make the most of cooperative learning, instructors need to form the teams so that they are diverse, be prepared to help teams manage conflict, address the entire class just enough to situate the day's topic in proper context, use an absolute grading scale, carefully plan group exercises, offer extra points to groups where all team members showed good understanding of the topic, and make attendance obligatory.

In addition, Goodwin, Hundley, Fox, and Wolter (1999) propose two approaches that engineering programs can implement to assist in the development of students' team-working skills. The first method suggests the creation of courses specifically designed to help students develop human behavior skills. The second approach suggests the creation of integrated courses 
in which there are two professors: an engineering professor who teaches an engineering concept and requires students to complete a group project, and a professor trained in team dynamics.

\section{Interpersonal skills}

A study conducted by Simmons (1999) revealed a fundamental set of five interpersonal skills that were most important to junior engineers and engineering managers, which included communication, team building, creative problem solving, conflict resolution, and negotiation. Many colleges of engineering are now seeing interpersonal skills as critical traits needed by graduates to be successful in their careers. The College of Engineering at the University of Texas-Austin, offers a special course designed for engineering students, "Interpersonal Communication Skills Training for Engineers", which provides engineering students with the opportunity to develop their interpersonal and group communication skills. The development of these skills enables engineering students to function better in both professional and personal relationships. Over a period of ten weeks, the one hour sessions deal with self-awareness and perception, verbal and non-verbal communication, leadership and power, defensiveness, team building, creative problem solving, communications and ethics, and conflict resolution (University of Texas)

Also, the College of Engineering at University of Wisconsin-Madison offers a course on Teams and the Engineering Profession. The course provides engineering students with the communication strategies necessary for effective teamwork in engineering and science professions. Key components of this class include: team structures and roles; leadership skills; group facilitation and conflict resolution; interpersonal skills and personality styles; research and analysis of team theories; application of team concepts to real-world issues; and evaluation of the team process (University of Wisconsin).

\section{Leadership skills}

An understanding of leadership skills are essential for effective management of multidisciplinary engineering activities. The ability to build project teams, motivate people, and create organizational structures conducive to innovative and effective work requires sophisticated interpersonal and organizational skills (Thamhain, 2004b). The importance of leadership is recognized by a number of engineering programs. For example, engineering students at Virginia Polytechnic University organize an annual Engineering Leadership Conference (Schwartz, 1998). Pennsylvania State University has developed a leadership minor to help engineering students bridge the gap between what they learn in school and what they will be expected to do in industry (Black, 1994). Another example is The Cooper Union, School of Engineering's Leadership in Engineering Advancing the Profession (LEAP) program. This leadership and professional development program is designed to offer engineering students a structured, yet flexible, selection of participatory leadership experiences, workshops, and courses. The LEAP's program goal is to cultivate the professional and interpersonal skills of engineering students and to enhance their leadership potential both in college of engineering and the workplace, thereby advancing the profession of engineering (Lyczko, 2000).

\section{Management skills}


Today's competitive global market and changing work environment demand that engineers possess management skills in addition to technical skills, and theymust be able to understand project goals and have the ability to accomplish them with available resources. Currently, engineers learn leadership and management skills while working-learning them the hard way. In order to meet the demands of this changing world, engineering programs are challenged to come up with innovative ways to teach classes so that graduates are prepared to take on the challenges twenty-first century engineers face (Morse \& Babcook, 2007). Increasingly, attention is given to the teaching of management and communication skills in engineering programs. The College of Engineering at the University of Texas-Austin offers a course on the Management of Software Project Teams. In this course engineering students study the complex role of today's software project manager. Global competition, downsizing, resource limitations, time-to-market, team building, conflict resolution, delegation, empowerment, marketing, communication, and leadership skills are topics that are covered this course (Dobbs, 2007). In addition, management courses are often offered jointly by Colleges of Engineering and Schools of Business.

\section{Ethical skills}

Engineering programs across the country are experimenting with new ways to integrate ethics into the engineering curriculum. For the most part, this has been motivated by criterion three of ABET's Engineering Criteria 2000 that requires that engineering programs demonstrate that their graduates have an understanding of professional and ethical responsibility (Kitto \& Sylvester, 2002). Engineering faculty are challenged to find an appropriate way to integrate material on ethics into their curricula. Instructors from Western Washington University's Engineering Technology Department teach engineering ethics by using both general case studies and specific case studies within the department. Students improve their oral skills by formally presenting case studies and leading class discussions about the ethical issues raised. Oral communications also reinforces effective writing. In an assignment engineering students write instructions for laboratory machines, non-disciplinary readers review the instructions. As a result, students learn not only how difficult it is to write clear instructions, but also how necessary it is, ethically and practically, to make instructions safe and useful for users from different backgrounds (Kitto \& Sylvester, 2002).

In addition, some schools such as the University of Detroit Mercy requires a single course on Politics and Ethics of Engineering for all engineering undergraduate students. Other schools such as Drexel University have chosen a more integrative approach that combines technical and non-technical material taught by both engineering and humanity instructors. The topics of study range from professionalism and case studies to readings in fiction and dramatized presentations by students (Stephan, 2002). Stanford University is another school that requires all engineering students to take at least one course on the interaction of technology with values and beliefs, social institutions, or behavior (Stephan, 2002).

\section{Life-long learning skills}


The ability for engineers to stay abreast of conceptual and technical developments in the engineering field and to deploy new knowledge in interdisciplinary contexts is increasingly essential (Jiusto \& DiBiasio, 2006). Universities in recent years have devoted attention to developing educational programs that promote learning that is necessary to prepare students for lifelong learning. For example, Worcester Polytechnic Institute's experiential Global Studies program engages its engineering students in semester-long, open-ended team projects executed in locations around the world, to assist in developing their lifelong learning readiness. The program goals include the ability to solve open-ended, multidisciplinary problems and understanding how technology and society interact. The students also have the opportunity to collaborate and work in teams. Another lifelong learning example is at Marietta College in Ohio where students develop personal portfolios in their engineering courses. The students' portfolios include a systematic and purposeful collection of their goals for learning, work in progress, and reflections on their work and processes. The portfolios with reflective assessment support habit and discipline, promotes continuous improvement for students, and clarifies the relationship between course learning and life-long learning and career development. The portfolios focus engineering students' attention on the quality of the lifelong learning process (Cress \& McCullough-Cress, 1999).

\section{Emotional intelligence}

Emotional intelligence skills can be integrated within an engineering course effectively. For example, Rensselaer School of Engineering at Rensselaer Polytechnic Institute introduces their engineering design students to EI skills at the very start of the course (Riemer, 2003). The five simple secrets of success (rapport, empathy, persuasion, cooperation, consensus building), as suggested by Goleman (1998) are communicated to the students. The students then engage in recognition exercises of these aspects in groups throughout the course. These group exercises contributed to increased student awareness of these skills and improves students' communication skills and teamworking abilities. These exercises also include the delivery of oral presentations, which enhance the students presentation skills. Video playbacks of the oral presentations also stimulate reflection in the students (Ladyshewsky \& Gotjamanos, 1996). Role-playing exercises are also used which encourage self-awareness and contribute to the students' understanding of empathy.

Also, the University of Illinois, Department of Industrial and Enterprise Systems Engineering offers a one semester course on Interpersonal Skills and Emotional Intelligence. The course provides students with the opportunity to develop their interpersonal and emotional intelligence skills. The course topics include understanding emotions in self and others, assessing and improving interpersonal skills and emotional intelligence competencies including: selfregulation, motivation, empathetic listening, communication, collaboration and cooperation, conflict management, leadership, teamwork, and managing change. Participation in the class is voluntary and students must be at least juniors or seniors in their engineering major (University of Illinois).

\section{Creativity}

There are many ways to design classroom assignments or teamwork activities to develop 
creativity in engineering. Some engineering professors make creativity an explicit component of their courses (Ghosh 1993; Masi 1989; Richards 1998). Torrance encourages instructors to develop constructive, as opposed to critical attitudes in themselves and in their classrooms. In a series of experiments "students who assumed a constructive rather than a critical attitude toward available information were able to produce a larger number of creative solutions as well as more original ones" (Torrance, 1977, p. 34). A few programs such as Olin College and Worcester Polytechnic Institute even go to great lengths to cultivate creativity throughout their curricula (Sanoff, 2003). For example, at Olin College of Engineering students in their project design course are given the opportunity to set their imaginations free to generate multiple, original ideas and solutions to real world problems in the field of engineering. Students are given the freedom to explore by setting aside time in the course for guided brainstorming and other creative acts such as looking at their ideas form several different points of views and coming up with multiple hypotheses (Sanoff, 2003). Another example is at University of Nevada-Reno were freshman students in mechanical engineering students work in teams to design and build LEGO machines and structures in classroom exercises that simulate the industrial design process. This teambased, hands-on approach not only encourages creativity and helps in recruitment of students, it also gives them "an overview of engineering practice and exposure to the environment that engineers generally work in” (Wang 2001, p. 11).

\section{Conclusions}

The future success of engineering graduates will increasingly depend not only on solid training in scientific and engineering principles, but also a more rigorous education in human behavior skills. As stated above there are many different educational approaches that universities are using to develop human behavior skills in engineering students. Some engineering curricula include "liberal arts' subjects in undergraduate programs. Others teach isolated human behavior skill classes, separate from the rest of the engineering curriculum. Additionally, other universities integrate different aspects of human behavior skills into their engineering core courses. Still in a few universities some engineering courses are taught jointly with faculty from other disciplines, such as humanities or business. In some schools specialists or consultants are brought in to conduct workshops or seminars related to human behavior skills. Many of these approaches have achieved some successful outcomes for their own institutions and have influenced the development of new approaches and ideas in engineering education. However, despite these efforts the engineering education reviews still reflect dissatisfaction with engineers' human behavior skills ability and competence (Hsu, 2004; Nguyen, 1998; Riemer, 2004;

Selinger, 2003)

Engineering is not only a discipline of study, but also a community of practice, human behavior skills for engineering practice must incorporate an understanding and knowledge of the interrelation of communication, team-working, interpersonal, leadership, management, ethical, communication, life-long learning, emotional intelligence, and creativity in a more planned and systematic way. These are the skills that are critical for successful professional development and fall into the larger category of human behavior skills needed for engineers in order to assurance that engineers can apply their technical knowledge in today's ever-changing and multidisciplinary world (see Figure 1). 
Recent studies have shown that both technical knowledge and human behavior skills are closely bound together when it come to career success of engineers (Cookie \& Miggs, 2005; Nguyen, 1998; Riemer, 2004; Watson, 2000). As the engineering graduate's required skills base continues to expand and evolve beyond the basic technical engineering knowledge, universities need to recognize that the skills base now needed in the knowledge era has extended to a greater need of human behavior skills. Human behavior skills offers more than just learning tools for the engineering student, but also life-long career skills. Human behavior skills are not a standalone fad, but rather an element that can have a significant impact on an engineering student's education and his/her future career. Furthermore, the globalization of private industry and other organizations will continue at increasing levels. Consequently, the professionals involved in international business will need to be equipped with new and expanded competences and skills from an intercultural perspective. Technical skills alone are no longer sufficient for advancing engineering education. Human behavior skills are a prime component that will facilitate the adaptation of future engineering graduates in an intercultural and global world.

Goleman (1999) has stated that engineering education has ignored human behavior skills in the past, skills that incorporate communication and collaborative abilities, teamwork, selling an idea, accepting criticism and feedback, learning to adapt, and leadership. He further stated that when engineers are promoted to leadership positions, they often lack the requisite leadership and managerial skills. These human behavior skills need to be planned and systematically integrated into the engineering curricula for engineering to regain relevance in education, across disciplines, society, and the world. This means that students, educators and leaders in educational institutions need to be educated in human behavior skills. By providing the right engineering curricula contents, universities can seize the opportunity to contribute in shaping the future engineer who has the skills and understanding needed to make vital contributions to society and the world. 


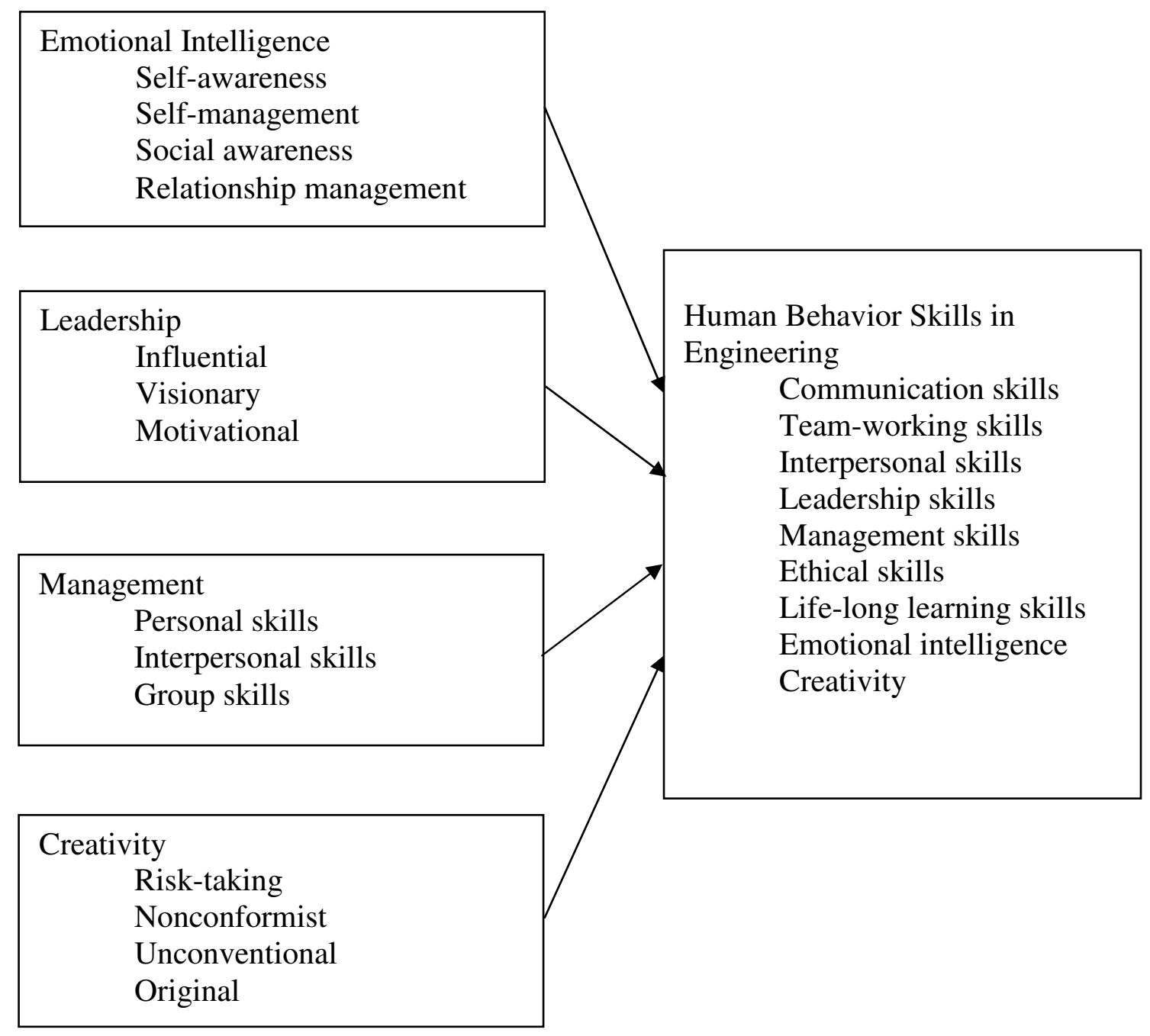

Figure 1. Human Behavior Education in Engineering Model. 


\section{REFERENCES}

ABET (2000). Engineering criteria 2000 $\square$ third edition. Retrieved March 20, 2006, from http://www.ele.uri.edu/faculty/daly/criteria.2000.html

ABET. (2004). Sustaining the change: A follow-up report to the vision for change. Retrieved February 1, 2006, from http://www.abet.org/papers.shtml

Angelo, W.J. (2001). Central artery needs funding boost for changes and claims. Engineering News Record Magazine, 247, 6, 19.

Ashley, S. (1993). The making of an effective manager. Mechanical Engineering, 115, 61-63.

Askew, P.E., \& Price, R.L. (2003). Advancing student leadership development. Proceedings of NASPA, Leadership Exchange, 12-16.

Atkinson, P.H. (1989, September). Adult learning and the engineer. Chemical Engineering Progress, 14-19.

Baldwin, L. (1996, May). Reengineering your learning strategy. Chemtech, 10-14.

Baren, R., \& Watson, J. (1991, September). Communications skills development within the engineering curriculum. Proceedings of the Frontiers in Education Conference, 419-424.

Bekir, N., Cable, V., Hashimoto, I., \& Katz, S. (2001). Teaching engineering ethics: A new approach. Proceedings of the ASEE Annual Frontiers in Education Conference, 1, 1-3.

Bellinger, R. (1998). Professional development sessions dominate; new poll on engineers' image released---PACE conference hits a year of transition. Electronic Engineering Times, 5-7.

Beer, D. F. (2002). Reflections on why engineering students don't like to write -- and what we can do about it. Proceedings of the International Professional Communication Conference, 364- 368.

Bjorklund, S.A., \& Colbeck, C.L. (2001). The view from the top: Leaders' perspectives on a decade of change in engineering education. Journal of Engineering Education, 1, 13-19.

Black, K. (1994). Industry view of engineering education. Journal of Engineering Education, 83, 1, 26-28.

Braham, J. (1992). Employers demand new skills. Machine Design, 19, 42-47.

Brungardt, C. (1996). The making of leaders: A review of the research in leadership development and education. The Journal of Leadership Studies, 3, 81-95.

Burns, G., \& Chisholm, C. (2002). Factors to be considered in replacing the traditional engineering curriculum approach by an undergraduate work-based learning approach. Proceedings of the 3rd Global Congress in Engineering Education, Glasgow, Scotland, UK, 35-38.

Cavalier, J.C., Klein, J.D., \& Cavalier, F.J. (1995). Effects of cooperative learning on performance, attitude, and group behaviors in a technical team environment. Educational Technology Research and Development, 43, 61-71.

Center for Creative Leadership. (1994). The realities of management promotion. San Diego, CA: CCL Press.

Chan, A.P.C., Ho, D.C.K., \& Tam, C.M. (2001). Effect of interorganizational teamwork on project outcome. Journal of Management in Engineering, 17, 34-40. 
Chen, S.J., \& Lin, L. (2004). Modeling team member characteristics for the formation of a multifunctional team in concurrent engineering. IEEE Transactions on Engineering Management, 51, 111-124.

Chisman, J. A. (1987). Helping students to speak and write. The Applied Journal of Engineering Education, 3, 2, 187-188.

Clapham, M. M. (1997). Ideational skills training: A key element in creativity training programs. Creativity Research Journal, 10, 33-44.

Cookie, L., \& Miggs, S. (2005). Connecting usability education and research with industry needs and practices. IEEE Transactions on Professional Communication, 48, 3, 296-312.

Crawford, A.S. (1998, June/July). Leadership education at the University of Michigan. Proceedings of the ASEE Annual Conference, 1-25.

Cress, D., \& McCullough-Cress, B. (1999). Reflective assessment: Portfolios in engineering courses. Proceedings of the Frontiers in Education Conference, 7-10.

Dahir, M. (1993). Educating engineers for the real world. Technology Review, 96, 14-16.

Dannels, D.P. (2002). Communication accross the curriculum and in the disciplines: Speaking in engineering. Communication Education, 51, 254-268.

Darling, A.L., \& Dannels, D.P. (2003). Practicing engineers talk about the importance of talk: A report on the role of oral communication in the workplace. Communication Education, 53, 1-16.

Davis, M. (1999, March). Teaching ethics across the engineering curriculum. Proceedings of International Conference on Ethics in Engineering and Computer Science, 21-24.

Dekker, D. L. (1995, August). Engineering design processes, problem solving and creativity. Proceedings of the International Association for Engineering Education Frontiers in Education Conference, 16-19.

DeLisle, P.A. (2000). Engineering leadership. IEEE Antennas and Propagation Magazine, 42, 131-134.

DiTomaso, N., \& Farris, G.F. (1992). Diversity and performance in R\&D. IEEE Spectrum, 6, 21-24.

Dobbs, T. (2007). Management of software project teams. Retrieved January 7, 2007, from lifelong.engr.utexas.edu/shortcourse.cfm?course_num $=1023$

Dreyfus, C.R. (1991). Scientists and engineers as effective managers: A study of the development of interpersonal abilities. Doctoral dissertation, Case Western Reserve University, Cleveland, Ohio.

Eck, R.W. (1990). Developing a civil engineer for the $21^{\text {st }}$ century. Journal of Professional Issues in Engineering, $116,156-163$.

Eichinger, R.W., \& Lombardo, M.M. (2004). The 6 Qs of leadership. Retrieved on April 12, 2006, from http://www.lominger.com/71.htm.

Farr, J.V. (1996). The impacts of technology on engineering education. Journal of Management in Engineering, 6, 25-26.

Felder, R. M. (1997). Creativity in engineering education. Chemical Engineering. Education, 22, 3, 120.

Fink, F.K. (2001, October). Modelling the context of continuing professional development. Proceedings of the $3 I^{\text {st }}$ ASEE Annual Frontiers in Education Conference, 19-23. 
Ghosh, S. (1993). Exercise in inducing creativity in undergraduate engineering students through challenging examinations and open-ended design problems. IEEE Transactions on Education, 36, 1, 113-119.

Goleman, D. (1998). Working with emotional intelligence. New York: Bantam Books.

Goleman, D. (1999). Engineers need emotional IQ. Engineering. News- Record, 242, 18, 167.

Goleman, D., \& Cherniss, C. (Eds.). (2001). The emotional intelligent workplace. San Francisco: Jossey-Bass.

Goodwin, C., Hundley, S.P., Fox, P.L., \& Wolter, R. (1999, November). The design, facilitation, and assessment of team skills in engineering curricula: Two delivery methods for an integrated curricula. Proceedings of the $29^{\text {th }}$ Frontiers in Education Conference, 21-23.

Gross, W.A. (2000). An approach to teaching entrepreneurship to engineers. IEEE Proceedings 2000, 648-652.

Hawkins, P., \& Barclay, I. (1990). Engineering and manufacturing engineers of the 1990s. Management DecisionQuarterly Review of Management Technology, 4, 44-51.

Hecker, P.A. (1997, November/December). Successful consulting engineering: A lifetime of learning. Journal of Management in engineering, 62-65.

Heller, M. (2001). Interdependencies in civil infrastructure systems. The Bridge, 9-15.

Hequet, M. (1995, October). Doing more with less. Training, 76-82.

Herkert, J.R. (2000). Engineering ethics education in the USA: Content, pedagogy, and curriculum. European Journal of Engineering Education, 25, 303-313.

Hilborn, R.B. (1994, August). Team learning for engineering students. IEEE Transactions on Education, $207-211$.

Hissey, T.W. (2000). Education and careers 2000. Enhanced skills for engineers. Proceedings of the IEEE, 8 , 1367-1370.

Honour, W.L. (1996, April). Integrating ethics and professional issues into a software engineering class. Proceedings of the $9^{\text {th }}$ Conference on Software Engineering Education, 259-269.

Hsu, C. (2004). Dilbert's Dilemma. US News and World Report, 54-59.

Illinois Leadership (n.d.). Skills. Retrieved March 14, 2006, from http://www.illinoisleadership.uiuc.edu/initiative/skills/

Jiusto, S., \& DiBiasio, D. (2006). Experiential learning environments: Do they prepare our students to be selfdirected, life-long learners? AREE Issues, 2,3, 1-3.

Johnston, D.L. (1987). Management for engineers. UK: Peter Peregrinus Ltd.

Kaye, S. (1998). Effective communication skills for engineers. IIE Solutions, 9, 44-47.

Kelley, R. E. (1999). How to be A star at work: 9 breakthrough strategies you need to succeed. New York, NY: Three Rivers Press.

Kitto, K.L., \& Sylvester, B. (2002, November). A multidisciplinary approach to teaching ethical considerations in engineering technology. Proceedings of the $32^{\text {nd }}$ Annual ASEE Frontiers in Education Conference, 1-6.

Ladyshewsky, R., \& Gotjamanos, E. (1996). Oral communication skill development using drama and videotape 
technology: an experiential learning approach. Proceedings of the Australian Communication Conference, Melbourne, Australia, 39-46.

Lang, J.D., Cruse, S., McVey, F.D., \& McMasters, J. (1999, January). Industry expectations of new engineers: A survey to assist curriculum designers. Journal of Engineering Education, 43-47.

Lannes, W.J. (2001). What is engineering management? IEEE Transactions on Engineering Management, 48, 1, $107-110$

Lingard, R., \& Berry, E. (2002, November). Teaching teamwork skills in software engineering based on an understanding of factors affecting group performance. Proceedings of the Frontiers in Education Conference, 1-5.

Loui, M. C. (2004). Engineering courage: The social construction of self-confidence in a course of professional ethics. Unpublished research study, University of Illinois at Urbana-Champaign, Urbana-Champaign, IL, USA.

Loui, M. C. (2005). Ethics and the development of professional identities of engineering students. Journal of Engineering Education, 94, 4, 383-390.

Lovgren, R.H., \& Racer, M.J. (2000). Group dynamics in projects: Don't forget the social aspects. Journal of Professional Issues in Engineering Education and Practice, 126, 156-165.

Lyczko, J. (2000). Leadership in engineering advancing the profession (LEAP). Proceedings of the ASEE/IEEE Frontiers in Education Conference, 20-24.

Manseur, R. (2003, November). An ABET-Based seminar course. Proceedings from the $33^{\text {rd }}$ Frontiers in Education Conference, 1-4.

Masi, J. V. (1989). Teaching the process of creativity in the engineering classroom. Proceedings of the IEEE Frontiers in Education Conference, 288-292.

McDonald, D. (1995). Integrating cooperative learning experiences in an instrumentation and control course. Proceedings of the 1995 ASEE Annual Conference, 1, 807-813.

McGinn, R.E. (2003). "Mind the gaps": An empirical approach on engineering ethics. Science and Engineering Ethics, 9, 517-542.

Midwinter, J.E. (1999, December). The challenge of lifelong learning. Engineering Science and Education Journal, 271-280.

Miles, M. B., \& Huberman, A. M. (1994). Qualitative data analysis: A sourcebook of new methods (2nd ed.). Newbury Park, CA: Sage.

Morse, L. C., \& Babcock, D. L. (2007). Managing engineering and technology. Upper Saddle River, NJ: Prentice Hall.

Munroe, A. S. (1995, January 26). Is your design a life sentence? Machine Design, 156.

Nguyen, D.Q. (1998). The essential skills and attributes of an engineer: A comparative study of academics, industry personnel, and engineering students. Global Journal of Engineering Education, 2, 65-76.

North Central Regional Educational Laboratory, NCREL (n.d.), $21^{\text {st }}$ Century skills. Retrieved March $1^{\text {st }}$, 2006, from http://www.ncrel.org/engauge/skills/effcomm2.htm

Orsted, M. (2000). Software development engineer in Microsoft. ACM Press, 539-540. 
Palmer, G., \& Slavin, D. (2003). Graduate engineering professional development. Proceedings from the Professional Communication Conference, IEEE International, 183-188.

Passino, K.M. (1998). Teaching professional and ethical aspects of Electrical Engineering to a large class. IEEE Transactions on Education, 41, 273-281.

Pearce, T. (1998). Building personal skills into a master of engineering degree. Proceedings of the Global Congress on Engineering Education, Cracow, Poland, 369-372.

Pet-Armacost, J., \& Armacost, R.L. (2003, November). Enhancing communication and professional practice skills in an introductory engineering course. Proceedings of the $33^{\text {rd }}$ ASEE Annual Frontiers in Education Conference, 10-15.

Petcher, K. (1997, September). Landing a job requires soft skills. Electronic Engineering Times, 969.

Porbahaie, M.A. (1994). Engineers and managerial challenges: A transitional perspective. Civil Engineering, 64, 73-74.

Ramirez, L.M., Velez-Arocho, J.I., Zayas-Castro, J.L., \& Torres, M.A. (1998). Developing and assessing teamwork skills in a multi-disciplinary course. Proceedings from the Frontiers in Education Conference, 1-16.

Raskin, A. (2003). A Higher Plane for Problem-Solving. Business, 54-56.

Redfem, M.A. (1997). Engineering inherently includes management. Management and Engineering Digest, 31-32.

Richards, L. G. (1998). Stimulating creativity: Teaching engineers to be innovators. Proceedings of the IEEE Frontiers in Education Conference, 3, 1034-1039.

Richardson, P. (1996). The importance of marketing to engineers: From an engineering perspective. IEE Colloquium on Marketing, 31-37

Riemer, M. J. (2001). IQ versus EQ: Emotional intelligence and the graduate engineer. Proceedings of the 5th Baltic Region Seminar on Engineering Education, Gdynia, Poland, 79-82.

Riemer, M. J. (2003). Integrating emotional intelligence into engineering education. World Transactions on Engineering and Technology Education, 2, 2, 9-15.

Reimer, M. J. (2004). Incorporating emotional intelligence (EQ) skills into the engineering curriculum to facilitate communication competencies. World Transactions on Engineering and Technology Education, 3, 2, 231234.

Robar, T.Y. (1998). Communication and career advancement. Journal of Management in Engineering, 26-28.

Rosenbaum, B.L. (1986). Critical skills for successful technical professionals. Personnel, 10, 56-60.

Sageev, P., \& Romanowski, C.J. (2001, October). A message from recent engineering graduate in the workplace: Results of a survey on technical communication skills. Journal of Engineering Educations, 685-692.

Sanoff, A. P. (2003). Engineers for all seasons. Prism, 12, 5, 30-33.

Schwartz, R. A. (1998, March). Providing the leadership edge. ASEE PRISM, 18-20.

Seat, E., \& Lord, S.M. (1999). Enabling effective engineering teams: A program for teaching interaction skills. Journal of Engineering Education, 88, 385-390. 
Segal, J. (1997). Raising your emotional intelligence: A practical guide. New York: Henry Holt and Company.

Selinger, C. (2003). Stuff you don't learn in engineering school. IEEE Spectrum, 40, 49-52.

Simmons, M.E. (1999). The essential interpersonal skills for junior engineers and engineering managers. Doctoral dissertation, Union Institute, Cincinnati, Ohio.

Smerdon, E.T. (1997). Lifelong learning for engineers: Riding the whirlwind. Cost Engineering, 6, 21-22.

Smith, K.A. (1995). Cooperative learning: Effective teamwork for engineering classrooms. Proceedings of the $25^{\text {th }}$ Annual Frontiers in Education Conference, 1, 13-18.

Snyder, B. (1967). Creative students in science and engineering. Universities Quarterly, 21, 205-218.

Standler, R. B. (1998). Creativity in science and engineering. Retrieved January 6, 2007, from http://www.rbs0.com/create.htm.

Steiner, C. J. (1998). Educating for innovation and management: The engineering educators dilemma. International Association for Engineering Education Transactions in Education, 41, 1-7.

Steneck, N.H. (1999, June). Adopting engineering models and methods to teach engineering ethics. Proceedings of the ASEE Annual Frontiers in Education Conference, 20-23.

Stephan, K.D. (2002). Is engineering ethics optional? IEEE Technology and Society Magazine, 20, 6-12.

Stern, H.P., \& Pimmel, R.L. (2002, November). An instructional module for engineering ethics. Proceedings of the $32^{\text {nd }}$ ASEE Annual Frontiers in Education Conference, 13-18.

Sternberg, R. (1999). The Handbook of creativity. Cambridge, MA: Cambridge University Press.

Sternberg, R., \& Lubart, T. (1995). Defying the Crowd: Cultivating Creativity in a Culture of Conformity. Columbus, OH: The Free Press.

Stouffer, W., Russell, J., \& Oliva, M. (2004). Making the strange familiar: Creativity and the future of engineering education. Proceedings of the ASEE Annual Conference \& Exposition, 61-78.

Sunindijo, R. \& Hadikusumo, B. (2005). Benefits of emotional intelligence to project management : Study of leadership and conflict resolution style of project managers in Thailand. Proceedings of Research Week International Conference, 40-52. The Queensland University of Technology, Brisbane, Australia.

Tao, B.Y. (1993). Senior/sophomore co-class instruction: Teaching interpersonal management skills in engineering. Journal of Engineering Education, 82, 126-129.

Thackray, J. (1995, July). That vital spark (creativity enhancement in business). Management Today, 56-58.

Thamhain, H.J. (1992a). Developing the skills you need. Research Technology Management, 2, $42-47$.

Thamhain, H.J. (1992b). Managing effectively in technology-based organizations. New York: J. Wiley.

Thamhain, H.J. (1993). Managing engineers effectively. IEEE Transactions on Engineering Management, 30, 4 , 231-237.

Thamhain, H.J. (2004a). Leading technology-based project teams. Engineering Management Journal, 16, 2, 35-43.

Thamhain, H. J. (2004b). Managing innovative R\&D teams. R\&D Management, 33, 3, 297-312. 
Thomas, T.A. (1999). Co-operating to learn using JAD techniques. South African Computer Journal, 87-94.

Todd, R.H., Magleby, S.P., \& Sorensen, C.D. (1993). Designing a senior capstone course to satisfy industrial customers. Journal of Engineering Education, 82, 2, 92-100.

Torrance, E. P. (1977). Creativity in the classroom. National Education Association. Washington, D.C.

University of Illinois. Interpersonal skills and emotional Intelligence. Retrieved January 6, 2007, from http://www.iese.uiuc.edu/ugrad/courses/

University of Texas. Interpersonal communication skills training for engineers. Retrieved January 4, 2007, from www.engr.utexas.edu/studentlife/interpersonal.cfm.

University of Wisconsin. Teams and the engineering profession. Retrieved January 4, 2007, from www.engr.wisc.edu/epd/courses/epd265.html.

Visser, H. (2005). Leadership in performance and change. Doctoral Dissertation, Rand Afrikaans University, Auckland Park, South Africa.

Walker, K. (2000). Integrating writing instruction into engineering courses: A writing center model. Journal of Engineering Education, 89, 3, 369-376.

Wang, E. (2001). Teaching freshman design, creativity and programming with LEGOS and LABVIEW. ASEE/IEEE Frontiers in Education Conference, F3G11-F3G15.

Watson, P.G. (2000). A hirability study: The characteristics that cause an engineering student to receive a job offer. Doctoral dissertation, Michigan State University, East Lansing, Michigan.

Whetten, D.A., \& Cameron, K.S. (2002). Developing management skills. New Jersey: Pearson Education, Inc.

Whittaker, C.J. (1989). Maryland high technology electronics industry's approach to engineers' professional development. Doctoral dissertation, University of Maryland College Park, College Park, Maryland.

Wulf, W. A. (1998). Diversity in engineering. The Bridge, 28(4).

Yost, S.A., \& Mohankrishnan, N. (1998, June-July). Adventures in cooperative learning: an ongoing experiment. Proceedings of the 1998 Annual ASEE Conference.

Yurtseven, H.O. (2001). How does the image of engineering affect student recruitment and retention? A perspective from the USA. Proceedings of the 4th UICEE Annual Conference on Engineering. Education, Bangkok, Thailand, 62-65. 